\title{
Andiroba oil (Carapa guianensis Aubl) in the capture of the fruit fly (Anastrepha fraterculus Wiedemann) in Feijoa (Acca sellowiana (Berg) Burret)
}

\author{
Aceite de andiroba (Carapa guianensis Aubl) en la captura de la mosca \\ de las frutas (Anastrepha fraterculus Wiedemann), en Guayaba Serrana \\ (Acca sellowiana (Berg) Burret) \\ Joatan Machado da Rosa ${ }^{1 *}$, Mari Inês Carissimi Boff ${ }^{1}$, Paulo Antônio Gonçalves ${ }^{2}$, \\ Pedro Boff ${ }^{2}$, Marcelo Zanelato Nunes ${ }^{1}$
}

\begin{abstract}
The fruit fly Anastrepha fraterculus is considered the main pest of fruit trees, including feijoa, Acca sellowiana, in the southern region of Brazil. The aim of this study was to evaluate the effect of Carapa guianensis on A. fraterculus. The research was carried out in a feijoa orchard in Lages, State of Santa Catarina, from December 2009 to December 2010. The experimental design was of randomized blocks with four repetitions. The treatments consisted of andiroba oil at $0.5,1 \%$ and $2 \%$, associated with $5 \%$ hydrolyzed protein (Bioanastrepha ${ }^{\mathrm{TM}}$ ), which was also used alone as control. Andiroba oil at $1 \%$ and $2 \%$ reduced the attractive potential of hydrolyzed protein; also, fewer females were captured in these two treatments.
\end{abstract}

Key words: Tephritidae, Meliaceae, ecology, monitoring, sampling, repellency.

\section{RESUMEN}

La mosca de las frutas, Anastrepha fraterculus es considerada la principal plaga de frutales de clima templado en la región del Sur del Brasil. Existe poca información sobre el manejo y control de esta especie asociada a la guayaba serrana, Acca sellowiana. El objetivo de este trabajo fue evaluar el efecto del aceite de andiroba, Carapa guianensis, en el monitoreo de A. fraterculus. El experimento fue conducido en un cultivo comercial de guayaba serrana en el municipio de Lages, Santa Catarina, en el período de diciembre de 2009 a diciembre de 2010. El experimento diseñado fue de bloques aleatorios con cuatro repeticiones. Los tratamientos fueron constituidos por el aceite de andiroba en tres concentraciones, 0,5\%, $1 \%$ y 2\%, en asociación con proteína hidrolizada 5\% (Bioanastrepha®), que también fue utilizada sin mezcla, como testigo. El aceite de andiroba en las concentraciones de $1 \%$ y $2 \%$ redujo el potencial atractivo de la proteína hidrolizada y también un menor número de hembras de A. Fraterculus fueron capturadas en estos tratamientos.

Palabras clave: Tephritidae, Meliaceae, ecología, monitoreo, muestreo, repelencia.

\section{Introduction}

The feijoa (Acca sellowiana (Berg) Burret) is a fruit tree of the Myrtaceae family, found in the Brazilian Southern Plateau, whose distribution extends from Paraná to Rio Grande do Sul, and northeastern Uruguay, in Araucaria forests and natural grasslands (Mattos, 1990). The species A. sellowiana is popularly known as goiaba serrana, goiabeira-da-serra or feijoa. In English it is also called pineapple guava (Mattos, 1990; Ducroquet et al., 2000). Although it is cultivated in the south of Brazil, feijoa is also commercially cultivated in various regions of the United States, New Zealand, Colombia and Australia. Its fruits have a distinctive flavor and aroma. It contains bioactive components which, according to Weston (2010), may be sold as nutraceutical products.

The fruit fly Anastrepha fraterculus is frequently found in feijoa. It may attack up to $100 \%$ of the

1 Universidade do Estado de Santa Catarina, Depto de Agronomia, Centro de Ciências Agroveterinárias, UDESC. CEP: 88520000 - Lages, SC-Brasil. Caixa-Postal: 281.

2 Empresa de Pesquisa Agropecuária e Extensão Rural de Santa Catarina-EPAGRI.

* Corresponding author: joatanmachado@bol.com.br 
fruits, making them inadequate for consumption and sale. Global restrictions on pesticide use require less impactful management strategies, tolerating their occurrence at certain population levels. Currently, there is a worldwide concern to reduce the use of synthetic plant protection products, so that fruit production pursues ecological standards established by rules of integrated fruit production (Fachinello et al., 2003).

The monitoring of fruit fly populations in orchards is done with fly traps containing attractant food baits. The monitoring and knowledge of the number of fruit flies caught in the traps are used to support decision-making in relation to whether or not to control these insects, interpreted by the level of economic damage (Hickel, 2008). The use of repellent, deterrent and insecticide plants is an alternative management to organosynthetic insecticides to produce less environmental impact (Valente et al., 2007).

The andiroba, Carapa guianensis Aubl. of the Meliaceae family, is a tree that can reach up to $30 \mathrm{~m}$ high and $1.20 \mathrm{~m}$ diameter (Sampaio and Clement, 2000). It is widespread in the Neotropics and Tropical Africa, and may be found in the south of Central America, Colombia, Venezuela, Surinam, French Guiana, Peru, Paraguay and Brazil. The seeds of this species contain high oil content of the triterpene chemical group, called limonoids (andirobin, gedunin and epoxy azadiradione). These substances are proven antifeedants to insects (Mikolajczak, 1988; Ambrozin et al., 2006). Thus it becomes extremely important to develop studies using non-residual therapies such as the andiroba oil to serve as an auxiliary tool in reducing the attack of fruit flies on fruit trees of temperate climates.

This study aimed at evaluating the effect of andiroba oil on the capture of A. fraterculus in a feijoa orchard.

\section{Material and Methods}

The studies were carried out from December 2009 to December 2010 in a commercial feijoa orchard with 13-year-old trees, located in the experimental area of the Empresa de Pesquisa Agropecuária e Extensão Rural de Santa Catarina (EPAGRI), Lages, SC, (latitude 2748'31'S, longitude $50^{\circ} 19^{\prime} 50^{\prime \prime} \mathrm{W}$ ). The mean altitude in the region is $904 \mathrm{~m}$ with predominance of subtropical climate, harsh winters and average annual temperature of $16^{\circ} \mathrm{C}$. The experimental station has a continuous area of approximately 170 ha, surrounded by native grasslands, urban area, reforestation areas, and some natural forest remnants. The orchard's length was 1.5 ha with plants spaced at $1 \mathrm{~m}$ by $5 \mathrm{~m}$ between rows, with spontaneous intercrop vegetation cover with periodic clearing of undergrowth.

The experimental design was of randomized blocks with four treatments and four replications. Each repetition was composed of one McPhail type trap. The treatments consisted of andiroba oil in the concentrations of $0.5,1$ and $2 \%$, in association with $5 \%$ hydrolyzed protein (Bioanastrepha ${ }^{\mathrm{TM}}$ ). Hydrolyzed protein at 5\% was the control treatment.

Attractant solutions were placed in the yellow McPhail type traps at a dose of $200 \mathrm{~mL}$ per trap. The traps were set in the plants at a height of 1.6 to 2.0 meters above the soil surface and $12 \mathrm{~m}$ distant from each other. The andiroba oil used was from Natural Rural ${ }^{\mathrm{TM}}$.

Attractant solutions were renewed every week. The insects captured were separated from the attractant solution through a fine mesh plastic sieve and then washed in pure water and packed in $80 \mathrm{~mL}$ plastic pots containing $70 \%$ alcohol. The samples were taken to the Laboratory of Homeopathy and Animal Health of the Epagri Experimental Station of Lages, SC, where sorting, counting, sexing and species identification were performed, using the taxonomic key prepared by Zucchi (2000).

For statistical analysis, the data were transformed to $\sqrt{ }(x+1)$, followed by analysis of variance and comparison of means with the Tukey test $(\mathrm{P}<0.05)$, using the statistical program SASTM, version 9.1. The numbers of flies per trap (MAD) obtained for each evaluation were calculated based on the period in which the trap remained exposed since the immediately preceding revision.

\section{Results and Discussion}

A. fraterculus was the only species captured during the evaluation period, totaling 954 individuals. The prevalence of the fruit fly $A$. fraterculus, is similar to the statement made by Nora et al. (2000) that $A$. fraterculus is the species with widest distribution and greatest abundance in the apple producing regions of Santa Catarina, regions in which we observed the presence of the species Acca sellowiana. Hickel (1993) and Salles (1995) also mentioned this species as being most abundant in the southern region of 
Brazil. Comparing the attractiveness of different food baits during two harvests of apples in the region of São Joaquim, SC, Teixeira (2010) observed that $99.9 \%$ of the fruit flies captured were A. fraterculus.

Mixed with standard attractant, andiroba oil significantly reduced the number of flies captured in relation to the control which contained only the hydrolyzed protein (Table 1). The increment in andiroba oil doses decreased the capture of fruit flies. The control was responsible for capturing approximately $51.3 \%$ of the total number of individuals throughout the exposure period of traps. During the period of December 2009 to December 2010 the treatments containing a mixture with 0.5 , 1.0 , and $2.0 \%$ of andiroba oil captured $32.8 \%, 9.1 \%$ and $6.8 \%$ of the total of flies collected, respectively.

In the total of captured flies there were 550 females and 404 males. The results of several researches have shown that more female fruit flies are caught using fly hunting traps when proteinaceous attractants are used (Scoz et al., 2006). This behavior is possibly due to the need of intake of carbohydrates and protein compounds for the production and maturation of eggs.

The hydrolyzed protein, used as a standard attractant, and the treatment containing $0.5 \%$ andiroba oil captured the greatest numbers of flies (Table 1). Significantly more females were attracted by the only hydrolyzed protein treatment, while for males there was no significant difference among the treatments.

The traps containing 1 and 2\% andiroba oil presented low total and mean capture of female flies in relation to the control (Table 1). Thus increasing the dose of andiroba oil can increase the repellency effect, especially for females, which in the context of fruit production are more harmful.

The increased dose of andiroba oil mixed with attractant repelled the fruit fly significantly. This suggests that studies should be conducted to check the possibility of using the andiroba oil in other ways, such as via spray to repel and reduce the presence of the insect in the fruiting period of culture. The andiroba oil repellent effect on fruit fly was similar to other surveys with various species of insects. Miot et al. (2004) used andiroba oil as a phytotherapeutic drug in studies and concluded that the pure oil presented repellent effect against the sting of Aedes $s p$. In addition to the repellent effect, andiroba oil showed toxic action on the third and fourth instar larvae of Aedes albopictus, A. aegypti and flies of the genus Culex (Silva et al. 2004; Emerick et al. 2005). Ambrozin et al. (2006) observed that the oil extracted from the seeds of andiroba also presented toxic effect on the leafcutter ant Atta sexdens rubropilosa.

The effect of andiroba oil on the biology of the insects was reported by Sarria et al. (2007), using isolated limonoids of $C$. guianensis on the larvae of Spodoptera frugiperda and workers of A. sexdens rubropilosa. The limonoids prolonged the larval cycle of $S$. frugiperda, but reduced the weight of pupae and caused mortality levels over 50\%. When added to the diet of ants, limonoids caused $88 \%$ of mortality of workers. Studying the insecticidal activity of vegetable oils including andiroba oil on

Table 1. Fruit fly adults, Anastrepha fraterculus Wiedemann, captured in McPhail type traps installed in a feijoa orchard, from December 2009 to December 2010. Lages, SC, Brazil.

\begin{tabular}{lcccc}
\hline Treatment & $\begin{array}{c}\text { Total flies } \\
\left(\mathrm{N}^{\circ}\right)\end{array}$ & $\begin{array}{c}\text { Female } \\
\left(\mathrm{N}^{\circ}\right)\end{array}$ & $\begin{array}{c}\text { Males } \\
\left(\mathrm{N}^{\circ}\right)\end{array}$ & $\begin{array}{c}\text { Capture } \\
(\%)\end{array}$ \\
\hline $\begin{array}{l}\text { Andiroba } 0.5 \%+ \\
{ }^{1} \text { P.H. 5\% }\end{array}$ & $3.85 \pm 1.63 \mathrm{ab}$ & $2.20 \pm 0.90 \mathrm{ab}$ & $1.65 \pm 0.75 \mathrm{a}$ & 32.8 \\
$\begin{array}{l}\text { Andiroba } 1.0 \%+ \\
\text { P.H. 5\% }\end{array}$ & $1.07 \pm 0.57 \mathrm{~b}$ & $0.59 \pm 0.28 \mathrm{~b}$ & $0.49 \pm 0.30 \mathrm{a}$ & 9.1 \\
$\begin{array}{l}\text { Andiroba 2.0\%+ } \\
\text { P.H. 5\% }\end{array}$ & $0.80 \pm 0.09 \mathrm{~b}$ & $0.41 \pm 0.09 \mathrm{~b}$ & $0.39 \pm 0.04 \mathrm{a}$ & 6.8 \\
P.H. 5\% & $5.89 \pm 1.60 \mathrm{a}$ & $3.55 \pm 0.83 \mathrm{a}$ & $2.33 \pm 0.78 \mathrm{a}$ & 51.3 \\
V.C. $(\%)$ & 37.72 & 43.58 & 38.11 & - \\
\hline
\end{tabular}

The amounts are the means of four repetitions accompanied by the standard error of the mean.

Means followed by the same letters in the columns do not differ by a Tukey test $(p>0.05)$.

Original data; transformed into $\sqrt{ }(\mathrm{x}+1)$ for statistical analysis.

1: P.H.: $5 \%$ hydrolyzed protein. 
stored grains of Sitophilus zeamais, Coitinho \& Oliveira (2006) observed good performance in the reduction of the percentage of full adults.

According to Fernandes et al. (2006), andiroba oil at a concentration of 0.2 to $1.5 \%$ sprayed on the bean plants is recommended as an alternative treatment for Ceratoma tingomarianus. Fazolin et al. (2000) reported that andiroba oil in sprays inhibits the consumption of bean plants by $C$. tingomarianus. Freire et al. (2006) also observed repellent action of andiroba oil on egg laying in insects of the family Phoridae (Diptera), demonstrating it to be an alternative in the combat of larvae and adults that infest hives of Melipona compressipes manaosensis.

Table 2. Adults captured (females and males) of fruit flies, Anastrepha fraterculus (Wiedemann, 1830) (Diptera:

Tephritidae), per trap per day (MAD), during the effective fruiting period of feijoa, (2009/20010). Lages, SC, Brazil.

\begin{tabular}{clllll}
\hline \multirow{2}{*}{ Period } & \multicolumn{5}{c}{ Treatment } \\
\cline { 2 - 5 } & 1 & 2 & 3 & 4 & \\
\hline $\mathrm{dec} / 28$ & $0.03 \mathrm{a}$ & $0.00 \mathrm{a}$ & $0.00 \mathrm{a}$ & $0.14 \mathrm{a}$ & 0.52 \\
$\mathrm{jan} / 04$ & $0.00 \mathrm{a}$ & $0.03 \mathrm{a}$ & $0.00 \mathrm{a}$ & $0.00 \mathrm{a}$ & 0.25 \\
$\mathrm{jan} / 11$ & $0.03 \mathrm{a}$ & $0.00 \mathrm{a}$ & $0.00 \mathrm{a}$ & $0.00 \mathrm{a}$ & 0.25 \\
$\mathrm{jan} / 18$ & $0.11 \mathrm{ab}$ & $0.00 \mathrm{~b}$ & $0.03 \mathrm{ab}$ & $0.28 \mathrm{a}$ & 0.67 \\
$\mathrm{jan} / 25$ & $2.14 \mathrm{a}$ & $0.21 \mathrm{c}$ & $0.43 \mathrm{~b}$ & $1.96 \mathrm{ab}$ & 3.23 \\
$\mathrm{feb} / 01$ & $2.11 \mathrm{a}$ & $0.78 \mathrm{ab}$ & $0.60 \mathrm{~b}$ & $2.82 \mathrm{a}$ & 2.64 \\
$\mathrm{feb} / 08$ & $1.53 \mathrm{a}$ & $0.03 \mathrm{c}$ & $0.03 \mathrm{c}$ & $0.96 \mathrm{~b}$ & 1.26 \\
$\mathrm{feb} / 15$ & $0.32 \mathrm{~b}$ & $0.00 \mathrm{~b}$ & $0.00 \mathrm{~b}$ & $1.71 \mathrm{a}$ & 1.78 \\
$\mathrm{feb} / 22$ & $0.18 \mathrm{~b}$ & $0.00 \mathrm{~b}$ & $0.10 \mathrm{~b}$ & $1.07 \mathrm{a}$ & 0.87 \\
$\mathrm{mar} / 01$ & $0.25 \mathrm{ab}$ & $0.03 \mathrm{ab}$ & $0.00 \mathrm{~b}$ & $0.54 \mathrm{a}$ & 0.94 \\
$\mathrm{mar} / 08$ & $1.35 \mathrm{a}$ & $0.07 \mathrm{~b}$ & $0.00 \mathrm{~b}$ & $1.00 \mathrm{a}$ & 1.22 \\
$\mathrm{mar} / 15$ & $0.53 \mathrm{a}$ & $0.21 \mathrm{~b}$ & $0.03 \mathrm{~b}$ & $0.86 \mathrm{a}$ & 0.62 \\
$\mathrm{mar} / 22$ & $0.60 \mathrm{~b}$ & $0.10 \mathrm{~b}$ & $0.14 \mathrm{~b}$ & $1.68 \mathrm{a}$ & 1.73 \\
$\mathrm{mar} / 29$ & $0.85 \mathrm{a}$ & $0.18 \mathrm{~b}$ & $0.18 \mathrm{~b}$ & $1.03 \mathrm{a}$ & 1.02 \\
$\mathrm{apr} / 05$ & $0.61 \mathrm{ab}$ & $1.11 \mathrm{ab}$ & $0.32 \mathrm{~b}$ & $1.46 \mathrm{a}$ & 1.42 \\
$\mathrm{apr} / 12$ & $0.28 \mathrm{a}$ & $0.25 \mathrm{a}$ & $0.21 \mathrm{a}$ & $0.78 \mathrm{a}$ & 0.96 \\
$\mathrm{Mean}$ & $0.68 \mathrm{a}$ & $0.19 \mathrm{~b}$ & $0.13 \mathrm{~b}$ & $1.02 \mathrm{a}$ & - \\
\hline
\end{tabular}

* Means followed by the same letter compared in lines do not differ by a Tukey test $(\leq 0.05)$.

1: andiroba oil at $0.5 \%+5 \%$ hydrolyzed protein; 2 : andiroba oil at $1.0 \%+5 \%$ hydrolyzed protein; 3 : andiroba oil at $2.0 \%+$ $5 \%$ hydrolyzed protein; $4: 5 \%$ hydrolyzed protein.
The analysis of the capture of flies per trap per day (MAD) during the fruiting period of the feijoa differed only in the evaluations made on January 18, March 1, and March 22, 2010 (Table 2). In the period under consideration, the andiroba oil repellent effect was shown by the reduction of catches of fruit flies in 4.7 times less than the control. During the period of feijoa fruiting, the treatment containing only hydrolyzed protein showed the great capture of fly per trap per day, and was similar to the treatment containing only hydrolyzed protein or with $0.5 \%$ of andiroba oil. The treatments containing 1 and $2 \%$ andiroba oil and hydrolyzed protein presented a MAD lower than the mean, which shows the repellent effect under these concentrations in the whole evaluation period.

The treatment containing only hydrolyzed protein at 5\% presented capture levels of flies per trap/day greater than the action level for the application of insecticides suggested by Nora \& Hickel (2002). These authors suggested the adoption of the level of $0.8 \mathrm{fly} /$ trap/day for dome-type trap containing grape juice and 0.5 fly/trap/day for the other trap and attractive substances. The traps containing andiroba oil at doses of 1 and $2 \%$ exceeded the levels of action on two dates, February 12010 and March 292010 (Table 2). Therefore, the repellent effect of $C$. guianensis is shown by the reduction in the capture of fruit fly; moreover, this effect was proportional to the increase of the dose of andiroba oil mixed with standard attractive.

\section{Conclusions}

1. The different doses of andiroba oil mixed with hydrolyzed protein significantly reduced the capture potential of $A$. fraterculus.

2 . Due to the significant capture reduction presented by the treatments containing 1 and $2 \%$ de andiroba oil, new treatments must be carried out to test the repellent effect of this oil on A. fraterculus when applied on the leaves or fruits of the plants. 


\section{Literature Cited}

Ambrozin, A.R.P. et al.

2006. Limonoids from andiroba oil and Cedrela fissilis and their insecticidal activity. J. Braz. Chem. Soc., 17 (3): 542-547.

Coitinho, R.L.B.C.; Oliveira, J.V.

2006. Atividade inseticida de óleos vegetais sobre Sitophilus zeamais MOTS (COLEOPTERA: CURCULIONIDAE) em milho armazenado. Revista Caatinga, Mossoró, 19 (2): 176-182.

Ducroquet, J.P. H.J.; Hickel, E.R.; Nodari, R.O. 2000. Goiabeira Serrana (Feijoa sellowiana). Jaboticabal: FUNEP. (Série Frutas Nativas, 5), 66 p.

Emerick, S.; Prophiro, J.; Rossi, J. et al.

2005. Resultados preliminares do efeito larvicida do óleo de andiroba (Carapa guianensis) (Meliaceae) em mosquitos do gênero Culex (Diptera: Culicidae). In: CONGRESSO BRASILEIRO de MEDICINA TROPICAL, 41, Florianópolis. Anais... Florianópolis, [s.n.], 2005, pp. 44-45.

Fachinello, J.C.; Coutinho, E.F.; Marodin, G.A.B.; Botton, M.; May De Mio, L.L.

2003. Normas técnicas e documentos de acompanhamento da produção integrada de pêssego. Pelotas: Universidade Federal de Pelotas, Faculdade de Agronomia Eliseu Maciel, $92 \mathrm{p}$.

Fazolin, M.; Estrela, J. L.Fazov.; Pessoa, J.S.

2000. Avaliação do uso do óleo de andiroba Carapa guianensis Aubl., no controle da Cerotoma tingonarius Bechynebem em feijoeiro no Acre. In: CONGRESSO BRASILEIRO DE DEFENSIVOS AGRÍCOLAS NATURAIS, 1. Fortaleza. Anais... Fortaleza: Academia Paraense de Ciências.

Fernandes, M.C.A.; Leite, E.C.B.; Moreira, V.E.

2006. Defensivos alternativos: ferramenta para uma agricultura ecológica, não poluente, produtora de alimentos sadios. Niterói: PESAGRO-RIO, 22p. (PESAGRO-RIO. FAZO Informe Técnico, 34).

Freire, D. C. B; Brito-Filha, C.R.C. and Carvalho-Zilse, G.A. 2006. Efeito dos óleos vegetais de andiroba (Carapa sp.) e Copaíba (Copaifera sp.) sobre forídeo, pragas de colméias, (Diptera: Phoridae) na Amazônia Central. Acta Amaz. [online]; 36 (3): 365-368.

Hickel, E.R.

2008. Pragas das fruteiras de clima temperado no Brasil: guia para o manejo integrado de pragas. Florianópolis: Epagri, $170 \mathrm{p}$.

Hickel, E.R.

1993. Pragas do pessegueiro e ameixeira e seu controle no estado de Santa Catarina. Epagri : Florianópolis, 45 p. (Boletim técnico, 66).

Mattos, J.R.

1990. Goiabeira serrana. Fruteiras nativas do Brasil. 2. ed. Porto Alegre: Gráfica Ceue, 120 p.

Mikolajczak, K.L.

1988. A limonoid antifeedant from seed of Carapa procera. Journal of Natural Products, Washington, 51 (3): 606-610.

Miot, H.A.; Batistella, R.F.; Batista, K.A. et al.

2004. Comparative study of the topical effectiveness of the andiroba oil (Carapa guianensis) and DEET 50\% as repellent for Aedes sp. Rev. Inst. Med. Trop. S. Paulo, 45: 253-256.

Nora, I.; Hickel, E.R.; Prando, H.F.

2000. Moscas-das-frutas nos estados Brasileiros: Santa Catarina, p. 271-275. In: Malavasi, A.; Zucchi, R.A. (edit.). Moscas-das-frutas de importância econômica no Brasil: conhecimento básico e aplicado. Ribeirão Preto, Holos Editora, $327 \mathrm{p}$.

Nora, I.; Hickel, E.R.

2002. Pragas da macieira. In: Epagri. A cultura da macieira. Florianópolis, pp. 463-525.

Salles, L.A.B

1999. Efeito do envelhecimento e da decomposição do atrativo na captura de adultos de Anastrepha fraterculus (Wied.) (Diptera: Tephritidae). Revista Brasileira de Agrociência, 5 (2): 147-148.

Salles, L.A.B.

1995. Bioecologia e controle da mosca-das-frutas sul-americana. Pelotas: Embrapa-CPACT, 58 p.

Sampaio, P. de T.B.; Clement, C.R.

2000. Biodiversidade Amazônica: exemplos e estratégias de utilização. Manaus: Programa de Desenvolvimento Empresarial e Tecnológico, pp. 243-251.

Sarria, A.L.F.; Yamane, E.S.; Bueno, F.C.; Matos, A.P.; Fernandes,

J.B.; Silva, M.F.G.F.; Vieira, P.C.; Bueno, O.C.

2007. Atividade inseticida de limonóides isolados de Carapa guianensis sobre a lagarta-do-cartucho-do-milho e a formiga cortadeira. Anais da $30^{\mathrm{a}}$ Reunião Anual da Sociedade Brasileira de Química-SBQ.

Scoz L., P.; Botton, M.; Silveira, M.S.; Pastori, L., P.

2006. Avaliação de atrativos alimentares e armadilhas para o monitoramento de Anastrepha fraterculus (WIEDEMANN, 1830) (DIPTERA: TEPHRITIDAE) na cultura do pessegueiro (Prunus persica (L.) BATSH). Idesia [online], 24 (2): 7-13.

Silva, O.S.; Romão, P.R.T.; Blazius, R.D. et al.

2004. The use of andiroba Carapa guianensis as larvicide against Aedes albopictus. J. Am. Mosq. Control Assoc, 20: 456-457.

Teixeira, R.; Ribeiro, L.G.; Boff, M.I.C.; Zanardi, O.Z.

2010. Atratividade de iscas alimentares comerciais para mosca-das-frutas em pomar de macieira. Agropecuária Catarinense, 23: 84-88.

Valente, M.; Barranco, A.; Sellaive-Villaroel, A.B.

2007. Eficácia do extrato aquoso de Azadirachta indica no controle de Boophilus microplus em bovino. Arq. Bras. Med. Vet. Zootec., 59: 1341-1343.

Weston, R.J.

2010. Bioactive products from fruit of the feijoa (Feijoa sellowiana, Myrtaceae): A review. Food Chemistry, 121, pp. 923-926.

Zucchi, R.A.

2000. Taxonomia. In: Mala vasi, A.; Zucchi, R.A. Moscas-dasfrutas de importância econômica no Brasil: conhecimento básico e aplicado. Ribeirão Preto: Holos Editora. cap. 1, pp. 13-25. 
